\title{
The New Human Rights Paradigm: Convention on the Rights of Persons with Disabilities and its Implementation in India
}

\author{
Smitha S Nizar*
}

\section{Abstract}

As any other vulnerable group, the journey of persons with disabilities to be treated as equals with others was long. A change from the tragic picture of helpless beings, who live at the mercy of others to dignified humans, remained as a long cherished desire. The stereotypic social attitude towards persons with disabilities resulted in denial of their basic rights and fundamental freedoms. The widespread exclusion and extreme isolation of persons with disabilities from social institutions was the major reason why it was felt that specific human rights instruments to protect their rights were required. Albeit, the initial fail with unenforceable soft laws, later the human rights perspective started recognizing persons with disabilities as complete human beings with UNCRPD. It introduced a paradigm shift from prejudiced social perception of persons with disabilities as incomplete human beings to complete and equal humans on par with all others. This paper seeks to examine the paradigm shift brought by the United Nations Convention on the Rights of Persons with Disabilities (UNCRPD) and its impact in India within the theoretical framework of international obligation and constitutional perspective.

* Senior Assistant Professor, School of Law, Sastra University, Thanjavur; smithanizar@gmail.com 
Keywords: Human Rights Instruments, International Obligations, Persons with Disabilities, Rights of Persons with Disabilities Bill, 2014, UNCRPD

\section{Introduction}

The human rights approach views disability as arising from social oppression which should be addressed as a human rights issue. It challenges the traditional 'medical model' view of disability. The rights-based approach to disability essentially means viewing persons with disabilities as subjects of law. The final aim is to empower persons with disabilities and to ensure their active participation in political, economic, social, and cultural life in a way that is respectful and accommodating of their differences. This model has been rooted in UDHR and other specific soft laws which aim to protect the rights of persons with disabilities. The Universal Declaration of Human Rights, 1948(UDHR) states that, "all human beings are born free and equal in rights and dignity". ${ }^{1}$ Thus, the UN Charter and the subsequent Universal Declaration of Human Rights, 1948 brought forth recognition and affirmation of the inherent dignity and equal and inalienable rights of all human beings. In furtherance of this international commitment, various Group Specific International Instruments have also been brought to safeguard the rights of vulnerable and discriminated groups of people. Persons with disabilities are one such discriminated group.

\section{Human Rights Discourse for Disability}

The human rights approach challenges inequality and discrimination imposed on persons with disabilities. This approach seeks to promote the quality of socially marginalized groups beyond national borders. The rights-based approach to disability is normatively based on international human rights standards and operationally directed to enhance the promotion and protection of the human rights of persons with disabilities. This human rights instinct for persons with disabilities got recognized in the UN Convention on Rights of Persons with Disabilities, 2006 (hereinafter

1 Universal Declaration of Human Rights art.1, Dec. 10 1948, G.A. Res. 217A(III), U.N. GAOR, 3d Sess., U.N. Doc.A/810. 
UNCRPD). UNCRPD is a land mark step towards affirming the right to equality and non-discrimination to persons with disabilities.

UNCRPD is a culmination of rights affirmed by the earlier International Human Rights Instruments. Under the UNCRPD, disability is understood as a human rights issue and discrimination on the basis of disability is treated as a violation of human rights. The rights based approach towards persons with disabilities has been accorded full recognition in the UNCRPD. In order to comprehend the evolution of international law on persons with disabilities, it is necessary to describe the various instruments preceding the UNCRPD which were concerned with the rights of persons with disabilities.

\section{Pre- Convention Laws and the Rights of Persons with Disabilities}

Consequent to the desire for democracy and human rights after World War II, the United Nations unanimously adopted the Universal Declaration of Human Rights (UDHR) on December 10, 1948. Although the UDHR has no legal force, its authority is unparalleled, since it stands as the single most important ethical statement on human rights. Many legal experts accord the status of customary international law to UDHR. The standards and principles specified by the UDHR have been constantly developed by the international conventions on human rights, thereby greatly promoting the cause of human rights. After the adoption of the UDHR, the development of human rights has acquired new dimensions. The human rights cooperative system among all countries has been formed, and the cooperation and coordination among the countries are conducted on the basis of the international conventions on human rights. The appearance of the above new factors has enabled the world human rights cause to make further progress in all continents. The UDHR values determine the current human rights law on disability.

The two binding treaties, which are derived from the UDHR, are the International Covenant on Civil and Political Rights (ICCPR), and the International Covenant on Economic, Social and Cultural 
Rights (ICESCR) which were adopted in 1966. These three texts together form the International Bill of Human Rights. The Bill has a tradition of three centuries of human rights thinking and more than two millennia of natural law and has in turn inspired the formation of dozens of treaties.

The Declaration on Social Progress and Development, 1969, had made an explicit mention to persons with disabilities, wherein it had provided for the protection of the rights and welfare of children, the aged and the 'disabled'. ${ }^{2}$ It further made provision for the protection of the physically or mentally disadvantaged. ${ }^{3}$

However, this normative inclusion was not reflected in recognizing the equal rights of the persons with disabilities. National laws which did not recognize persons with disabilities as 'persons' before the law continued to hold the field. Consequently, a need was felt to have laws which particularly focused on disability.

\section{Early Efforts to Develop International Standards on Disability}

As an indication to the progress of status of persons with disabilities, the following soft law was adopted by UN, to develop international standards on disability: -

\begin{tabular}{|c|l|}
\hline 1971 & Declaration on the Rights of Mentally Retarded Persons \\
\hline 1975 & Declaration of the Rights of Disabled Persons \\
\hline 1981 & International Year of Disabled Persons (United Nations) \\
\hline 1982 & $\begin{array}{l}\text { World Programme of Action concerning Disabled } \\
\text { Persons }\end{array}$ \\
\hline 1989 & $\begin{array}{l}\text { Tallinn Guidelines for Action on Human Resources } \\
\text { Development in the Field of Disability,1989 }\end{array}$ \\
\hline
\end{tabular}

2 Declaration on Social Progress and Development, art.11(c), Dec. 11 1969, G.A. res. 2542 (XXIV), 24 U.N. GAOR Supp. (No. 30) at 49, U.N. Doc.A/7630 (1969).

${ }^{3}$ Id. 


\begin{tabular}{|c|l|}
\hline 1991 & $\begin{array}{l}\text { Principles for the Protection of Persons with Mental } \\
\text { Illness and for the Improvement of Mental Health Care } \\
4\end{array}$ \\
\hline $\begin{array}{c}1982- \\
1992\end{array}$ & $\begin{array}{l}\text { International Decade of Disabled Persons (United } \\
\text { Nations) }\end{array}$ \\
\hline
\end{tabular}

The Declaration on the Rights of Mentally Retarded Persons, 1971, proclaimed the necessity of protecting the right, welfare and rehabilitation of the physically and mentally 'disadvantaged'. It provided a common basis and frame of reference for the protection of rights of persons with mental disabilities. ${ }^{5}$ It accorded right to proper medical care, economic security, and right to live with family, and right to guardian for physically and mentally 'disadvantaged' people.

The Declaration of the Rights of Disabled Persons ${ }^{6}$ adopted by the UN General Assembly is the first international document that tried to define the term 'disability'. The Declaration included a number of social, economic and political rights. The Declaration asserted that persons with disabilities have the same civil and political rights as other human beings. It stated that the disabled persons have the inherent right to be respected for their human dignity. It declared that whatever be the origin, nature and seriousness of their disabilities, they have the same fundamental rights as their fellow citizens of the same age. The Declaration identified a number of economic and social rights that are of importance for the development of capacities and social integration. This Declaration

4 (It must be noted that this soft law instrument was not included in the perambulatory statement of the CRPD. The World Network of Users \& Survivors of Psychiatry has explicitly denounced this instrument as it was formulated without the participation of persons with disabilities).

5 (The term mentioned for persons with mental disabilities was 'mentally retarded persons', points out the prejudiced socio-legal perception sustained against persons with disabilities).

${ }^{6}$ General Assembly Resolution 3447 (XXX) of 9 December 1975. 
accorded the foremost right to enjoy a decent life as normal and to the fullest extent possible. ${ }^{7}$

A major outcome of the International Year of Disabled Persons (1981) was the formulation of the World Programme of Action Concerning Disabled Persons (WPA) in 1982. The WPA was a global strategy to enhance prevention of disability, rehabilitation and equalization of opportunities, which pertains to full participation of persons with disabilities in social life and national development. The WPA emphasized the need to approach disability from the human rights perspective.

Tallinn Guidelines for Action Human Resources in the Field of Disability (1989) considered the situation of human resources development in the field of disability, particularly in developing countries. It affirmed the necessity to reinforce existing activities to promote the further development and continued progress of disabled persons. It was one more step towards the protection of the rights of persons with disabilities.

The UN Standard Rules of 1993 is another main UN instrument on the rights of persons with disabilities. The Standard Rules are the most comprehensive set of human rights standards regarding disability. This document addressed issues such as preconditions for equal participation, target areas of equal participation, implementation measures and monitoring mechanisms. ${ }^{8}$ Standard Rules have defined disability by emphasizing the social conditions which disable a group of individuals by ignoring their need to access opportunities in a manner conducive to their circumstances. ${ }^{9}$

Proclamation of the Economic and Social Commission for Asia and the Pacific on the Full Participation and Equality of People with Disabilities in the Asian and Pacific Region (1993), focused on the expansion of opportunities for the full participation of people with disabilities and their equality in the development process. It aimed

7 General Assembly Resolution 3447 (XXX) art. 13(3) of 9 December 1975.

8 UN General Assembly, Standard Rules on the Equalization of Opportunities for Persons with Disabilities : Resolution / Adopted By The General Assembly, 20 December 1993, A/RES/48/96 available at http:/ / www.refworld.org/docid/3b00f2e80.html.

${ }^{9}$ Id. 
at encouraging the nations, international organizations, agencies and committed individuals to take action to achieve the goal of improving the quality of lives of people with disability. It was an indication of the progress in the status of persons with disabilities.

However, all these soft laws have focused on ensuring welfare of persons with disabilities, as they were viewed as helpless beings. The ominous silence about civil and political rights of persons with disabilities rendered rights of persons with disabilities negotiable. The Standard Rules provided voice to persons with disabilities by adopting the right to participation.

\section{Towards Rights Based Standards on Disability}

\begin{tabular}{|l|l|}
\hline 1993 & $\begin{array}{l}\text { UN Standard Rules on the Equalization of } \\
\text { Opportunities for Persons with Disabilities }\end{array}$ \\
\hline 1993 & $\begin{array}{l}\text { Proclamation of the Economic and Social } \\
\text { Commission for Asia and the Pacific on the Full } \\
\text { Participation and Equality of People with } \\
\text { Disabilities in the Asian and Pacific Region }\end{array}$ \\
\hline
\end{tabular}

The Standard Rules inaugurated a rights based discourse on disability. However, it is pertinent to note that, except for Standard Rules on the Equalization of Opportunities for persons with Disabilities ${ }^{10}$, all the other soft laws relating to disabilities endorsed the medical model. The language used to refer to persons with disabilities in the soft law shows the medicalised perception of disability. These soft laws which had adopted a welfare perspective towards disability continued to view persons with disabilities as individuals with medical problems, dependent on social security and welfare. Furthermore, even the entitlements guaranteed by these instruments were only incorporated in Declarations, Principles and Rules. These soft law instruments had no binding force in international law. Consequently, persons with disabilities continued to face discrimination and were often denied their human rights. The above scenario is reflected in national laws that denied the basic rights to persons with disabilities.

10 Adopted by General Assembly Resolution 48/96 of December 20, 1993. 
Albeit, Universal Declaration of Human Rights was a composite document incorporating both first generation rights (civil and political rights) and second generation rights (social and economic rights), the succeeding conventions introduced a divide between the two sets of rights. ${ }^{11}$ International human rights law has conferred immediacy and justiciability as two qualities to civil and political rights. This has contributed to the non negotiable visage of civil and political rights. ${ }^{12}$ Therefore no need was felt to guarantee to persons with disabilities the right to life, the most relevant civil right. However, the UNCRPD recognizes the right to life for persons with disabilities on an equal basis with others. ${ }^{13}$ This affirmation challenges the belief that a life with disability is a less valued life which need not be protected. ${ }^{14}$ In this context, it would be appropriate to describe the implications of the UNCRPD on the value of the life of persons with disabilities.

\section{The Implications of UNCRPD on the Value of Life of PWDs}

The United Nations Convention on the Rights of Persons with Disabilities (UNCRPD), together with its Optional Protocol, was adopted on December 13, 2006 and came into force as International Human Rights law on May 03, 2008. As the first human rights convention adopted in the twenty first century, the UNCRPD seeks to protect the rights of all persons with disabilities. It identifies the rights of persons with disabilities as well as the obligations on the State Parties to the Convention to promote, protect and ensure those rights. It treats the life of persons with disabilities as equally valuable as that of any other human being. The States that become parties to the Convention shall agree to promote, protect and ensure the full and equal enjoyment of all human rights and fundamental freedoms to all persons with disabilities, and to promote respect for their inherent dignity. The Convention is a

11 Amita Dhanda, Constructing a New Human Rights Lexicon: Convention on the Rights of Persons with Disabilities 50 SUR-INTERNATIONAL J. HuM. RTS. 82008.

$12 \mathrm{Id}$. at 46 .

13 Universal Declaration of Human Rights art.10, Dec. 10 1948, G.A. Res. 217A(III), U.N. GAOR, 3d Sess., U.N. Doc.A/810.

14 Dhanda, supra note 11 at 46. 
paradigm shift in approaches to disability. ${ }^{15}$ It is a shift from a model where persons with disabilities were treated as objects of medical treatment, charity and social protection to a model where persons with disabilities are recognized as subjects of human rights. 16

\section{Significance of UNCRPD}

The Convention on Rights of Persons with Disabilities (UNCRPD) is significant in many respects. It is not a mere anti discrimination convention. It provides a wide range of basic rights to persons with disabilities. The Convention breaks away from the state centric model of negotiation ${ }^{17}$ by according opportunity to persons with disabilities in the negotiation process. UNCRPD was adopted in the presence of persons with disabilities and their representative organizations from different parts of the world.

Prior to the Convention, disability was treated as the deficit of a person, which prevents them from enjoying their rights along with other people. This deeply entrenched attitude and stereotypes operated as barriers to the social participation of persons with disabilities. The Convention recognized the inherent dignity of all human beings. Consequently, the UNCRPD lays down unequivocally that persons with disabilities shall have equal access to full and effective enjoyment of all human rights. An examination of rights that affirms equality, dignity, non discrimination, right to life and right to health will be helpful to ascertain the status of persons with disabilities in the human rights paradigm.

15 Smitha Nizar, Impact of UNCRPD on the Status of Persons with Disabilities, IND. J. MED. ETH. VII(4) 2008, 227.

$16 \mathrm{Id}$.

17Tara J. Melish, Perspectives on the UN Convention on the Rights of Persons with Disabilities: The UN Disability Convention: Historic Process, Strong Prospects, and Why the U.S. Should Ratify, HUMAN RIGHTS BRIEF 14(2) 2007. 


\section{Equality and Non Discrimination}

Article 5 of the Convention explicitly addresses the right to equality and non discrimination which states that:

1. States Parties recognize that all persons are equal before and under the law and are entitled without any discrimination to the equal protection and equal benefit of the law.

2. States Parties shall prohibit all discrimination on the basis of disability and guarantee to persons with disabilities equal and effective legal protection against discrimination on all grounds.

3. In order to promote equality and eliminate discrimination, States Parties shall take all appropriate steps to ensure that reasonable accommodation is provided.

4. Specific measures which are necessary to accelerate or achieve de facto equality of persons with disabilities shall not be considered discrimination under the terms of the present Convention.

Right to equality in general affirms that all human beings are born free and equal. Right to equality for persons with disabilities also envisages the same and provides respect to the diversity to accommodate persons with disabilities. This means that laws, policies and programs should not be discriminatory, and that the public authorities should not apply or enforce laws, policies and programs in a discriminatory or arbitrary manner. Non discrimination is an integral part of the right to equality.

The formal approach recognizes that all are equal before the law.18 The more substantive approach specifically prohibits discrimination on the basis of disability. ${ }^{19}$ State parties are required

18.Universal Declaration of Human Rights art.5(1), Dec. 10 1948, G.A. Res. 217A(III), U.N. GAOR, 3d Sess., U.N. Doc.A/810.

19. Universal Declaration of Human Rights art.5(2), Dec. 10 1948, G.A. Res. 217A(III), U.N. GAOR, 3d Sess., U.N. Doc.A/810. 
to combat any form of discrimination as defined by Article 2 . Accordingly, discrimination means;

Discrimination on the basis of disability means any distinction, exclusion or restriction on the basis of disability which has the purpose or effect of impairing restriction or nullifying the recognition, enjoyment or exercise, on an equal basis with others, of all human rights and fundamental freedoms in the political, economic, social, cultural, civil or any other field. It includes all forms of discrimination, including denial of reasonable accommodation.

The UNCRPD aims to apply the principle of equality and non discrimination to every human right. Human equality is central to the system of basic freedoms postulated by human rights law. Its core premise is that all persons not only possess inherent self worth, but are also inherently equal in terms of self worth, regardless of their differences. It means that a just society is one that has a positive approach towards human differences. ${ }^{20}$ Valuing human difference is validated by the human rights perspective of the UNCRPD. From one angle, equality focuses on the need for even handedness by the parliaments when they create distinctions in law and policy. This interpretation of formal or juridical equality is, of course, vital and will continue to form the bedrock of any understanding of equality.21 It seems equality and non discrimination are necessary rights to make other rights meaningful and to produce real change. The human rights paradigm of the Convention has been further strengthened by the right to life and health.

20.Gerard Quinn and Theresia Degener, The Current Use and Future Potential of United Nations Human

Rights Instruments in the Context of Disability (New York and Geneva: United Nations 2002) http://uncrpd.nileshsingit.org (Visited on March 11, 2014).

21. $I d$. 


\section{Right to Life}

Article 10 of the Convention states that, "State Parties reaffirm that every human being has the inherent right to life and shall take all [the] necessary measures to ensure its effective enjoyment by persons with disabilities on an equal basis with others." The term 'reaffirm and shall recognize' have been used to strengthen the text and to make it clear that 'right to life' includes the 'right to survive'. The main reason for the inclusion of right to life in the treaty lies in the stereotypes and prejudice of the society against persons with disabilities. The lives of persons with disabilities are under threat because others think that their lives are not 'worth living'. Therefore the affirmation of right to life in itself challenges the belief that a life with disability is a less valued life and hence it does not need to be protected. 22

Thus, if we ask the question as to what UNCRPD has done to persons with disabilities, mainly it has signaled the change from charity to rights perspective, by affording recognition of equal status with others and by providing autonomy with support and by consideration of disability as an inherent human condition. ${ }^{23}$ India was one among the first few States to become party to this universal law.

\section{General Obligations of State Parties under the UNCRPD}

Article 4 of the UNCRPD requires State Parties to promote the full realization of human rights and fundamental freedoms for all persons with disabilities, without discrimination of any kind by;

1. Adopting legislative, administrative and other measures to implement the rights contained in the CRPD.

2. Adopting legislative, administrative and other measures to abolish discrimination against persons with disabilities.

23 Dhanda, supra note 11. 
3. Not engaging in any act or practice that is inconsistent with the CRPD and ensuring that the public sector acts in conformity with the CRPD.

4. Taking measures to eliminate discrimination on the basis of disability

5. Involving persons with disabilities in developing and implementing legislations and policies and in all decision making process related to persons with disabilities.

Accordingly, as a State Party, it is India's obligation to eliminate discrimination on the basis of disability. Apart from these specific general obligations stipulated under the UNCRPD, international obligation is a constitutional mandate for India.

\section{Ratification of UNCRPD and India's Human Rights Obligation}

The UNCRPD came into force in May, 2008. India has both signed and ratified the Convention. ${ }^{24}$ Consequently, the Convention has become an operative and binding international law for India. It is an established proposition in international law that a State is bound by the provisions of an international law once it deposits the instrument of ratification. As States are bound by the treaties they rarify, they should discharge their obligations in good faith. ${ }^{25}$ Moreover, the international human rights obligation has a 'special character', as it deals with the obligations of States towards individuals rather than between the States. ${ }^{26}$ Especially, more explicit protection of specific groups of people is envisaged under specific human rights instruments. The UCRPD and its human rights discourse has emanated as a part of the rights based strategy for the benefit of the marginalized and excluded groups. Therefore,

24 (While ratification brings in a positive obligation, signature inducts a negative duty with the ratified States).

25 InTERnAtional Human Rights LAW 125 (Daniel Mockeli, Sangeeta Shah, et.al. eds., Oxford University Press, 2010).

${ }^{26} \mathrm{Id}$. at 127. 
it can be said that the UNCRPD is an outcome of the 'struggle for new human rights'. ${ }^{27}$ The paradigm shift introduced by UNCRPD deepens and broadens rights based approach in support of persons with disabilities and enunciates the right to inclusion and full participation of persons with disabilities. Thus ratification of UNCRPD has brought a strong legal obligation on India to ensure the enjoyment of human rights to persons with disabilities.

States assume obligations and duties under international law to respect, to protect and to fulfil human rights. The obligation to respect means that the States must refrain from interfering with or curtailing the enjoyment of human rights and the obligation to protect requires the States to protect individuals and groups against human rights abuses. The obligation to fulfill means that States must take positive action to facilitate the enjoyment of basic human rights.

In turn, ratification obligates the States to provide a substantive framework for the application of rights within domestic law and policy. ${ }^{28}$ Civil and Political Rights are broadly thought to include prevention of state interventions with rights such as the right to life, movement, thought and expression, association, religion and political participation commonly referred to as negative rights. The indivisibility of rights is an integral theme that runs right through the treaty and systematically highlights both the negative and positive dimensions of all rights. For example, Article 5 which guarantees equality and non discrimination states that "In order to promote equality and eliminate discrimination, States Parties shall take all appropriate steps to ensure that reasonable accommodation is provided". It has become clear that, without a positive duty to promote substantive equality, patterns of discrimination and social exclusion will remain unchanged.29 Thus the Convention

27 The International Struggle for New Human Rights (Clifford Bob ed., University of Pennsylvania Press, 2009).

${ }^{28}$ Rosemary Kayess \& Philip French, Out of Darkness into Light? Introducing the Convention on the Rights of

Persons with Disabilities 8(1) HuM. RTS. L. R. 2008, 1-34, 1.

29 S. Fredman, "Disability Equality: A Challenge to the Existing AntiDiscrimination Paradigm?", in A. Lawson and C. Gooding (ed.), 
incorporates highly disability specific interpretations of existing human rights, which transform negative rights into positive State obligations.

\section{Constitutional Aspects of International Obligation}

The Indian Constitution has provisions that relate to the compliance with international treaties and conventions. Article 51 of the Indian Constitution, as a part of promotion of international peace and security states that, "The State shall endeavour to...(c) foster respect for international law and treaty obligations in the dealings of organised people with one another".

Article 253 further provides power to make any law as a part of international obligation. It states that, "Notwithstanding anything in the foregoing provisions of this Chapter, Parliament has power to make any law for the whole or any part of the territory of India for implementing any treaty, agreement or convention with any other country or countries or any decision made at any international conference, association or other body".

Despite several international conventions and treaties not having been enacted into municipal law, courts have been relying on the principles of international treaties, especially the human rights treaties, to interpret domestic law. In Gramophone Company of India Ltd. v. Birendra Bahadur Pandey and Others ${ }^{30}$, the Supreme Court has held that due regard must be given to international conventions and norms for construing domestic law. The Indian Supreme Court has passed a landmark judgment in Vishaka and Ors v. State of Rajasthan and $\mathrm{Ors}^{31}$ wherein it relied on the provisions of The Convention on the Elimination of All Forms of Discrimination Against Women (CEDAW) to apply the principle of right to life and dignity for women at the workplace. The Supreme Court has also recognised the concept of legitimate expectation of the observance of the international obligations if there is a void in the domestic law.

DisAbility Rights in EUROPE: FROM THEORY TO PRACTICE199(Oxford: Hart Publishing, 2005).

30 Gramophone Company of India Ltd., A.I.R. 1984 S.C. 667.

31 Vishakha, (1997) 6 S.C.C. 241. 
Thus the Indian Constitution brings her courts under an obligation to see that the message of the international instruments is not allowed to be drowned. In the light of this obligation, it would be worthwhile to examine India's commitment to bring the new human rights paradigm shift to recognize persons with disabilities as equals.

\section{The Implementation of UNCRPD in India}

The conundrum of sameness and difference which has haunted every excluded group in its journey of inclusion was avoided in UNCRPD by seeking both the same and the different. ${ }^{32}$ Thus whilst persons with disabilities are entitled to the same respect and dignity as the rest of the humanity; they are also entitled to reasonable accommodation ${ }^{33}$ of their difference in order to obtain the outcome of inclusion and full participation. ${ }^{34}$ The right to reasonable accommodation has been taken into account by Indian judiciary also.

A recent judgment of the Bombay High Court has applied the principle of reasonable accommodation enshrined in the UNCRPD in the domestic context, in the case of Ranjit Kumar Rajak v. State Bank of India. ${ }^{35}$ In this case, the petitioner was declared medically unfit for employment as an officer in the State Bank of India. He had previously undergone a renal transplant, but was fully capable of carrying out the duties of the job he had applied for. The respondent bank refused to select him on the ground that his monthly medical expenses, which would be borne by the bank,

${ }^{32}$ Dhanda, supra note 11.

33 (UNCRPD Article 2 defines reasonable accommodation to mean necessary and appropriate modification and adjustments not imposing a disproportionate or undue burden, where needed in a particular case, to ensure to persons with disabilities the enjoyment or exercise on an equal basis with others all human rights and fundamental freedoms) Universal Declaration of Human Rights art.2, Dec. 10 1948, G.A. Res. 217A(III), U.N. GAOR, 3d Sess., U.N. Doc.A/810.

34 Universal Declaration of Human Rights art.5(3), Dec. 10 1948, G.A. Res. 217A(III), U.N. GAOR, 3d Sess., U.N. Doc.A/810.

35 Ranjit Kumar, 2009(5) BomCR 227, MANU/MH/0452/2009. 
would be substantially high as he had undergone a renal transplant.

The Bombay High Court rejected the bank's contention and directed them to appoint the petitioner for the job by providing reasonable accommodation in the form of medical expenses. The court held that "reasonable accommodation if read into Article 21 of the Indian Constitution guaranteeing the right to life, based on the Disabilities Convention, would not be in conflict with municipal law and on the contrary it would give added life and dimension to the ever expanding concept of life and its true enjoyment". 36

It may be assumed that the expanded formulation will also be applicable to persons with disabilities. ${ }^{37}$ There are not many cases (both pre-CRPD and post- CRPD stage) or where the Indian courts have deliberated upon the content of the right to life for persons with disabilities. The courts have however been required to address right to life in its survival manifestations for the persons with disabilities. The Bombay High Court in Niketa Mehta ${ }^{38}$ case which discussed abortion in case of disabilities also has a bearing on the right to life of persons with disabilities.

However, in this case the Court was not concerned with the question of the value of life with disability which has informed the induction of Article 10 in the UNCRPD. In this case, Niketa Mehta was 26 weeks pregnant when her doctor diagnosed the foetus as having a congenital heart block. Since Ms Mehta's pregnancy had

36 Ranjit Kumar, 2009(5) BomCR 227, MANU/MH/0452/2009.

37 (For instance, Right to life in India is perceived as 'not restricted to 'mere animal existence', but imported human dignity into its peripheries in Francis Coralie Mullin v. Administrator, Union Territory of Delhi, (1981) 1 S.C.C. 608; A.I.R. 1981 S.C. 746. Right to life was interpreted and extended to many rights such as right to live with human dignity in Bandhua Mukti Morcha v. Union of India (1984) 3 S.C.C. 161; right to free and compulsory education in Unnikrishnan v. State of Andhra Pradesh, [1993]1 S.C.R. 594; right to privacy in Kharak Singh v State of U.P., 1963 Cri. L. J. 329; right to healthy environment in M.C. Mehta v. Union of India, A.I.R. 1988 S.C. 1037; right to health in Consumer Education and Resource Centre v. Union of India, (1995) 3 SCC 42 etc.). 38 Nikhil D. Dattar and Ors. v. Union of India, (2008)110 Bom. L. R. 3293. 
crossed the legally permitted time limit of 20 weeks for medical termination under the Medical Termination of Pregnancy Act, 1971 (MTP Act), the petitioners approached the Bombay High Court seeking judicial interference in the specific provisions of the MTP Act in order to permit medical termination. The court has rejected termination on technical grounds as it is not legally possible for the court to allow for termination of pregnancy beyond the time limit of 20 weeks. This reflects the non adjudication of the issue in the light of UNCRPD, which accorded value of life to persons with disabilities.

However, we can see the judicial impact of UNCRPD, when it recognized the reproductive right of women with disabilities. In Suchita Srivastava v. Chandigarh Administration, ${ }^{39}$ the Punjab and Haryana High Court ordered the termination of the pregnancy of a 19-20 years old unmarried, women with disability. She was an orphaned woman residing in a state-run institution for the 'mentally challenged' in Chandigarh. In spite of the Medical Board's findings that the woman had expressed her willingness to bear a child and was physically fit to do so, the High Court ordered to terminate pregnancy, 'in the best interest of the petitioner'. However considering the case on another set of premises, the Supreme Court stayed the order of the High Court with the view that the termination of the pregnancy was not in the best interest of the petitioner. Taking cognizance of reproductive rights, it ruled that a woman's right to reproductive decision making is a dimension of the right to liberty under Article 21 of the Constitution. The Supreme Court ruling is path breaking as it unequivocally endorses respecting the autonomy of persons with mental disabilities in the area of reproductive choice. ${ }^{40}$ Thus, the Supreme Court has recognised the legal capacity of a woman with intellectual disability to take decision about her body and to carry on with her pregnancy.

We can see here the slow process of judicial interpretation to give complete meaning to the universal rights in the absence of a

39 Suchita Srivastava v. Chandigarh Administration, A.I.R. 2010 S.C. 235: (2009) 9 S.C.C. 1.

40 Renu Addlakha, A Commentary on the case. (I owe the author a lot for sending me the personal copy of the paper). 
domestic law that reflects the human rights or the CRPD paradigm shift.

\section{Legislative Efforts in Tune with UNCRPD in India}

In view of the rights guaranteed under the UNCRPD India has initiated revisiting all the related laws in order to harmonize it with the convention. India is on her way of preparation of a new law for persons with disabilities. In the proposed draft, right to life has found an appropriate place in an expanded manner. According to the working draft ${ }^{41}$ of the proposed new law, Right to life includes the right to live with dignity, which includes but is not limited to:

a) Adequate nutrition, clothing and shelter;

b) Access to facilities for reading, writing and expressing one-self in any form or language whether written, spoken, unspoken, or sign language; and

c) Freedom of movement, association, participation and living and sharing with other persons and communities.

d) Opportunity to acquire personal, social, educational and vocational skills required to function as a person with disability;

e) Right to legal capacity on all aspects of life on an equal basis with others and access to any support or arrangements necessary for the exercise of legal capacity.

41 Working Draft of the Rights of Persons with Disabilities Act, 2010 http://www.disabilitystudiesnalsar.org. (A working draft is the preliminary form of possible future document prepared by a working committee. It indicates the commitment on the part of the legislature to do further work on the working draft. Draft put out by ministry to seek the stakeholder or public opinion is the final draft. Sec. 3(1) of The Rights of Persons with Disabilities Bill 2014, states that, "The appropriate Government shall ensure that the persons with disabilities enjoy the right to equality, life with dignity and respect for his or her integrity equally with others"). 
However, the Rights of Persons with Disabilities Bill, 2014 shows how hard it is for persons with disabilities to avail civil and political rights. Sec. 3(1) of this Bill enunciates right to life, discarding the needs of persons with disabilities. Accordingly, "the appropriate Government shall ensure that persons with disabilities enjoy the right to equality, life with dignity and respect for his or her integrity equally with others".

To bring Indian laws in line with international obligations, the Bill was originally drafted, following a thorough pre-legislative deliberative process with the stakeholders. ${ }^{42}$ Yet, the legislation approved by the Cabinet has no relationship with the original draft, a progressive rights based law. When embedded in a regressive law, even progressive provisions can fail to see adequate implementation. ${ }^{33}$ Amita Dhanda points out that;

It would be infinitely preferable to build consensus around a robust legislation instead of spending the next few decades hoping for positive judicial interpretation and clamouring for legislative amendments. ${ }^{4}$

It shows that, the legislative attempt to accustom the International commitment, has given minus mark for India. The Disability Rights Bill, diluted by the executive, demonstrates how hard it is for person with disabilities to avail their rights without negotiating it. Does it suggest that the universal paradigm shift from considering persons with disabilities as objects to equal subjects of law has not reached India so far?

42 Amita Dhanda, A Retrograde and Incoherent Law, THE HiNDU 6 Feb. 2014 at 9; Faizan Mustafa, NALSAR Disassociates itself from Disability Bill, THE HINDU 6 Feb. 2014. (A legislation, which was drafted on a consistent deliberation with the stakeholders, finally became a 'mincemeat' at the hands of executives as termed by Faizan Mustafa. He called it as a 'breach of trust' and an 'act of impropriety' on part of the State. According to him, the new Disability Bill 2014, has negated the benefits of the existing law as interpreted by the Supreme Court).

${ }^{43} \mathrm{Id}$.

44 Id. 


\section{Conclusion}

The UNCRPD becomes important and it has several provisions for protection of persons with disabilities in India. It declares the basic rights to equality and non discrimination and to the protection of the right to life and dignity for all persons with disabilities. The Disabilities Convention, much like the Indian Constitution, propounds the interdependence and indivisibility of both civil and political rights. The non discrimination ideal in the Convention can be seen as a vision for inclusive society. The Convention insists on the existence of non-discrimination laws and the obligation of providing 'reasonable accommodation'. The Right to life accorded by the CRPD is far reaching in India, in the light of the persisting constitutional trend of providing complete respect to international law. Entrusting the expansion of rights under CRPD on judiciary, without a fairly tuned domestic law would call for many other decades to realize the universal rights. The entire meaning of the 'paradigm shift' brought by the new human rights paradigm renders meaningless if India could not gear up the failed legislative action. This would leave CRPD and its ratification by India, a romantic nonsense. 